\title{
樹脂チューブ用超音波シール機の開発
}

\author{
福島庄次 望月 隆 加藤元三郎
}

\section{Development of Ultrasonic Sealer for Plastic Tubes}

\author{
Shoji Fukushima, Takashi Mochizuki, Motosaburou Katou
}

Commercially available seamers for plastic tubes generally use heat or high frequency but they have such problems as difficult sealing if the internal surface of the tube is contaminaited with its contents.

Particularly, when the tube content is viscous and has thread-forming properties or is of low viscosity and readily forms droplet the probability of defective sealing due to contamination increases resulting in consumers.

The authors have initiated a study aiming at the development of a perfect sealing method even if the appropriate parts of tube are contaminated with the contents. In this study, heat sealing and high-frequency sealing wealing were not considered to be suitable to solve the problems and methods employing ultrasonic energy were examined under various conditions. Favorable results were obtained by the use of diagonal vibration as the vibration source and a honeycomb shape for the pattern.

\section{1. 緒 专}

現在市場汇出回っている樹脂チューブのシール方法と しては，䏶シール・または高周波シールが一般的である が，いずれもシール部の内面に充填物が仆着するとシー ルができないといら問題がある。

特に充填物の粘度が高く洩糸性を有する埸合や，低粘 度で飛沫化しやすい場合などでは，充埧物が付着してシ 一ル不良を起す確率が高くなり，消費者のクレームが多 発することになる。我々は, 内容物が付着してる確実に シールできる方法の開癹を目的として本研究に着手し た。開発の狙いとしては, 熱シール法や高垌波シール法 では，解決が困難と考克，新しい技術として超音波振動 エネルギーを㐫用する方法について種々の条件下で倹討 を加え, 振動方法としては, 斜め振動。パターン形状と しては，ハニカム型を採用することにより，断期の目的 を達することが出来たので報告する。

ポーラ化成工業(侏静岡研究所: 静岡市弥生町648 R \& D Laboratories POLA Corporation; 648 Yayoi-cho, Shizuoka

\section{2. 結 棵}

\section{2-1 超音波シール機}

・試験用超音波シール機（ポーラ自社開発）(Photo）

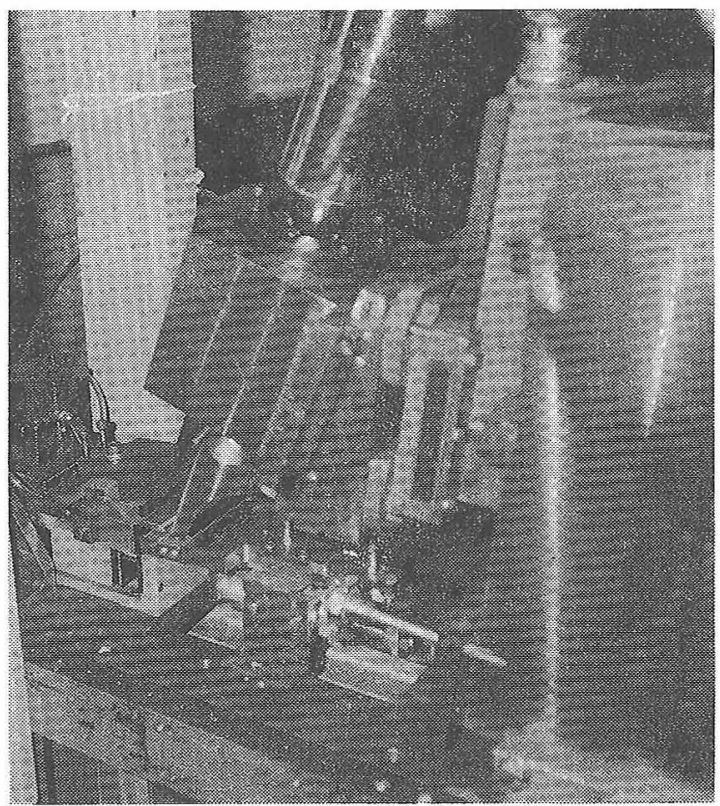




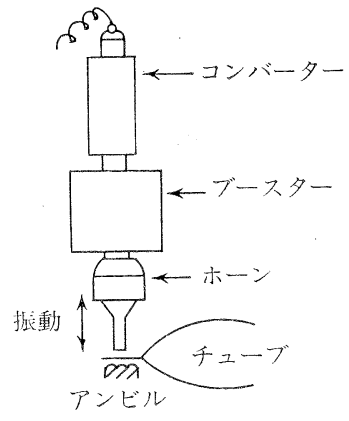

1) 縦振動方式

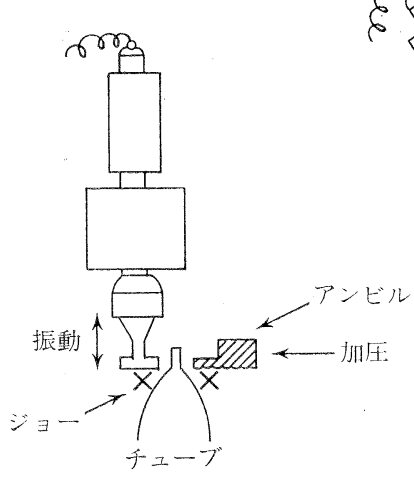

2) 横振動方式

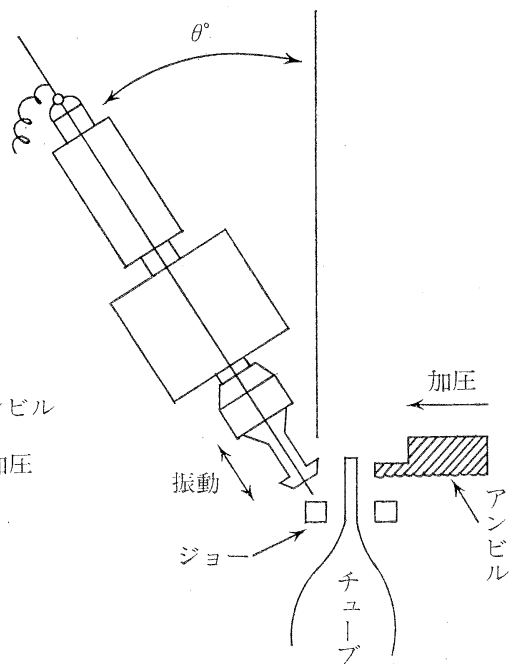

3) 斜め振動方式

Fig.-1

- 超音波発振機 : $20 \mathrm{KHZ}$

・アンビル加圧シリンダー：ボアー $\phi 30 \mathrm{~mm}$

- 加圧方法 : 油压利用

\section{2 超音波振動方式}

従来から使用されている 1) 縦振動方式，2）横振 動方式, に加えて新しく 3) 斜め振動方式について検 討した。斜め振動方式については傾斜角度 $\theta$ の影響につ いてもテストした (Fig.-1)。

\section{3 シール面のパターン形状}

シール面のパターン形状としては，1) 縦線型，2） 横線型，3）ピラミッド型，4）斜め型。新しく考案した 5 ）八ニカム型の 5 種類について検討した $(\mathbf{F i g . - 2 ) 。 ~}$

$$
\text { パターン名 }
$$$$
\text { 形状 }
$$

1. 維 線 型

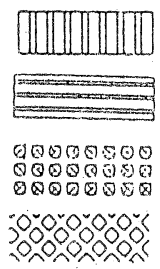

Fig.-2

\section{4 チューブ材澌と形状について}

材質については一般的に使用されている低密度ポリェ チレン (LDPE)。内容物の多様化に伴って最近使用さ れ始めた多層チューブ（中密度ポリエチレン／エチレ
ソ，ビニールアルコール $/ \mathrm{MDPE}$ )。霜磨き等に使用さ れている AL ラミネートチューブの 3 種類について検討 した。

チューブ内径は, $\phi 13, \phi 22, \phi 25, \phi 30, \phi 45$

肉厚保, t $0.3, \mathrm{t} 0.36, \mathrm{t} 0.45$

\section{5 内容物}

シール面への付着を起こし易い下記 3 種について検討 した。

1) 浅系性が非常に高いピールオフタイプのパック 料。

2）低粘度で飛散性が高いファンデーション類。

3）高粘度で付着するとシール性が非常に悪くなる洗 顔クリーム，季た特殊な例として食品（バタ一，マ ヨネーズ), 工業製品(接着剤ボンド, シリコーングリ 一ス)についてもテストした。その結果を(Table1) 示す。

\section{6 シール性能の評価}

1) シールの外靚

パターン, ロットナンバーの鮮明度, バリ発生度を目 視で部価する。

2) シール独度

圧縮力, 舢荷重で評值。

測定機 : テンシロン UTM-111-100

条 件：常温。压縮スピード $1.00 \mathrm{~mm} / \mathrm{min}$ 圧縮面積 $\phi 60 \mathrm{~mm}$

3) シール時間 
Table-1

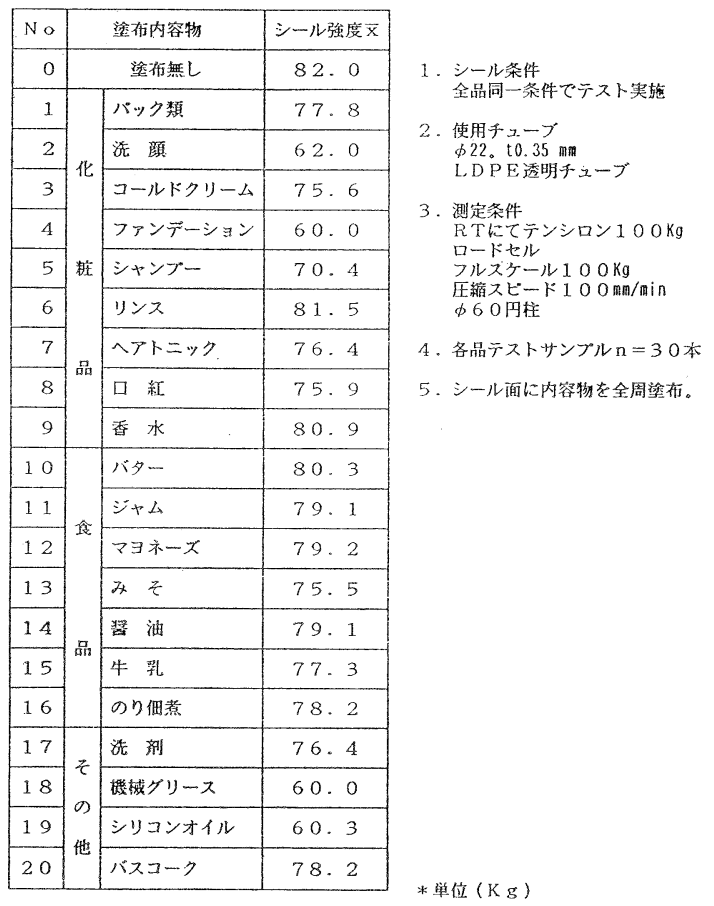

1 本当りシールにかか古案時間。

4）付着物の飛散性

透明チューブのシール面に内容物を塗布。シール後パ ターン部分に内容物が残っているかを目視で評価する。

5）シール音

シール時に発生する溶着音

\section{3. 結果と考察}

\section{1 振動方式の影響}

低密度ポリエチレンチューブを用い, シール面にピー ルオフタイプのパック料, ファンデーション類, 洗顔ク リームを塗布して, 振動方式の優劣を比較実験した。結 果をTable-2 に示す。

従来の縦振動, 横振動方式と比較して, 斜め振動方式 ほ全ての評価項目が優れて和り良好な結果である。また 斜め振動に於ける角度 $\theta$ の影響について子種々の実験を 行った結果, 内容物の飛散力とシール外観が特に $20^{\circ}$ 前 後が最良であった。斜め振動方式で好結果が得られたの は, シール内面に付着した内容物を振動エネルギーによ って上下方向にシール外観を損らことなく効率よく我散 させる為と推定する。

しかし, シール部と胴部のさかいにピンホール, 溶着
Table-2

\begin{tabular}{|c|c|c|c|}
\hline 項 目 & 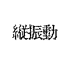 & 桡振動 & 斜为握動 \\
\hline 1. 内容物の飛散力 & $x$ & 0 & 0 \\
\hline 2. シーム外钼 & 0 & $\times$ & $\mathrm{O}$ \\
\hline 3. シーム強度 & 小 & 小 & 大 \\
\hline 4. シームの安定性 & 中 & 小 & 大 \\
\hline 5.シーム時䦓 & 短か心 & 曼 い & 短分心 \\
\hline
\end{tabular}

洔バリが何かの贾因で発生することがあり未解決であ る。

\section{2 斜め振動方式によるシールパターンの影響}

振動方式の比較で斜め振動は優れていることが判明し たが更にシールパターンの形状が振動伝達に重要である と考光検討を加光た。

内容物としては飛散しにくいと思われる，ピールオフ タイプのパック料を選定, チューブ材質は低密度ポリエ チレンを使用, Fig.-2 に示したパターンの形状 4 種に ついて, 同一条件下でテストした。結果をまとめると

Table-3 の如くである。

Table-3

\begin{tabular}{|c|c|c|c|c|c|}
\hline パターン形䜤 & 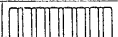 & $=$ & $=1$ & 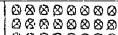 & 300000 \\
\hline 項自 & 1)䋮 線 型 & 2)䟧 & 線 型 & 3)ピララッド型 & 4)斜 め 型 \\
\hline 1.シーム撪度 & 弱 小 & & 小 & 中 & 大 \\
\hline 2. シ 一 $\Delta$ 外 観 & $\mathrm{O}$ & & 0 & 0 & 0 \\
\hline 3. 摩 攃熱 & 弱小 & & 小 & 小 & ф \\
\hline 4. 内容物の拡散力 & 弱 小 & & 小 & 中 & 大 \\
\hline 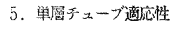 & $\triangle$ & & $\triangle$ & $\triangle$ & (c) \\
\hline 6. 多居チューブ適応性 & $x$ & & $x$ & $\Delta$ & $\Delta$ \\
\hline
\end{tabular}

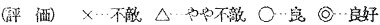

1) 縦線型，2）横線型は凹部面が大きく，樹脂面と でスりップが発生, 振動によるエネルギーが内部に伝達 されず内部発熱が小さい。

束た付着した内面の内容物を瓜散させる力が小さい。

2）ピラミッド型は凹部が尖って特り，樹脂へのくい 込久は良くスリップを防ぐが，凹部先端のフラット面が ないため発熱が小さい。

3 ）斜め型は各項目ともほぼ良好な結果であるが，多 檿チューブでの適応性はシール時の発熱不足で十分な溶 着が得られない結果でせる。

\section{3チューブ材質とパターン形状の影響}

多層チューブは，異融点材質の組合わせである。今ま 
でのパターン形状ではクリアーできない為にパターンの 役割について見直した。

1）効率の良いエネルギーの伝達。

2）振動による摩擦熱の発生。

3）溶融樹脂の流れ抵抗の均一化。

以上の役割を満たすパターン形状が多曆チューブでは 尚一層求め (必要)られることが推定された。種々のパ ターン形状について赛験し六角形の八ニカムを考案し た Fig.-3)。
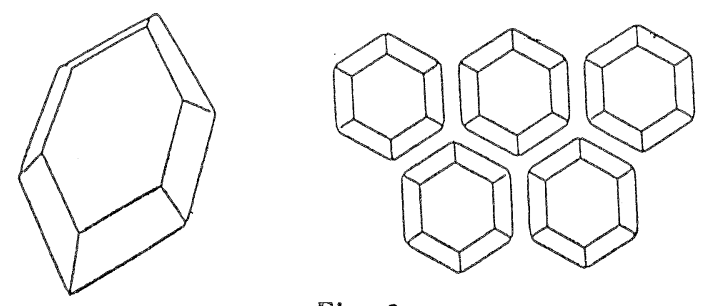

Fig. -3

\section{4 内容物の影響}

最終確認として斜め振動と八ニカムパターンの組 合 せでチューブ材質は最もシールが困難である多層チュー ブ (MDPE／エバール/MDPE), 外径 $\phi 22$, 肉厚 t 0.45 を用いて前述の $2-5$ に示す全ての内容物を塗布したテ
ストでは良好な結果を得て。但しファンデーション類， 洗顔クリームは若干シール強度が下がる傾向にあること が解った。

\section{4. 総 括}

樹脂チューブ用の斜め振動方式による超音波シール機 を開発し当初の目的を達成した。るたチューブ材質の シール可能な範囲をハニカムパターン考案により㹡大す ることが出来た。

その結果

1.シール内面に内容物が付着してもシール可能。

2. 単層, 多層チューブでもシール可能。

3. シール時の音が小さい。

4. 外観品質の向上。

5. シール強度の安定性。

以上の項目が満足された。

今迄、シール内面に内容物が付着すると『シール出来 ない。』といら概念は今後消えて行くであろら。化粧品 以外の他分野でも広く活用が期待される優れた方法であ ると考觉る。

現在, この方法は PUF-2000 型（超音波シール付チ ューブ充填機）として実用化されるに至った。

(昭和 62 年10月12日受理) 